\title{
Enhancing the Scope of Vegetable Cultivar Evaluation in Florida
}

Donald N. Maynard

\begin{abstract}
AdDitional INDEX WORDs. specialty vegetables, variety trials
Summary. Vegetable cultivar evaluations are conducted seasonally by research and extension faculty at several locations throughout the state of Florida. Results are summarized and published in a Florida Agricultural Experiment Station Circular, Vegetable Variety Evaluation in Florida and used as a basis for extension recommendations published in Vegetable Production Guide for Florida, an industry-sponsored publication. The selection of vegetables to be evaluated depends on local needs and the evaluator's interest. Until recently, this has provided fairly good coverage of the principle vegetables grown in the state. However, the future of this program as currently structured may be in doubt because of changes in assignments of current faculty, new faculty with assignments and interests that differ from their predecessors, and reduced administrative recognition for cultivar evaluation. It is likely that county extension faculty and professional staff will have a greater role in cultivar evaluation as university faculty input is reduced. Increasing the scope of vegetable cultivar evaluation by university faculty to include adaptation of new crops and specialty vegetables adds a new dimension to traditional trials. Some of these vegetables have not benefitted from selection or breeding so there is opportunity for crop improvement as a further extension of vegetable cultivar evaluation.
\end{abstract}

$\mathrm{V}$ egetable cultivar evaluation is especially important in Florida because of the large number of new introductions made by the seed industry and because of the large number of crops that are commercially grown. Florida, situated between latitudes $24^{\circ} 30^{\prime}$ and $31^{\circ} \mathrm{N}$ and longitudes $80^{\circ}$ and $87^{\circ} \mathrm{W}$, is largely lowland peninsula that provides an array of climatic zones from subtropical to temperate. Furthermore, the state is surrounded on three sides by waters of the Atlantic Ocean and Gulf of Mexico which limits transfer of data from adjoining areas.

The objective of the vegetable cultivar program in Florida is to evaluate recently released cultivars, advanced experimental, and specialty vegetables for their potential for commercial production. Standard cultivars are included in each trial.

Vegetable cultivar research is conducted under State Project 03553, Vegetable Variety Evaluation in Florida. There are 14 investigators, not all active each year, at 10 locations around the state. An annual publication, Vegetable Variety TrialResults in Florida (Maynard and Olson, 2001a) that summarizes the statewide cultivar evaluation effort is produced as a Florida Agricultural Experiment Station Circular. Since trial results accumulate through December, it is not possible to have this document prepared before April of the following year.

Vegetable cultivar evaluation as an extension activity is conducted under State Major
Program FL 107, Vegetable Production, Harvesting and Handling Efficiencies in Florida. A publication-Vegetable Variety Evaluation Demonstrations: A Manual for County Extension Faculty (Maynard, 1987) - has been prepared to assist in planning, execution, and reporting of cultivar evaluations by county extension faculty. Participation is based on the perceived needs of county growers, technical support available, grower cooperation, and interests of the faculty member. Results from research and extension trials are incorporated into an annual industry-sponsored publication Vegetable Production Guide for Florida (Maynard and Olson, 2001b), which is available in printed and electronic formats.

\section{Future cultivar evaluation}

Cultivar evaluations by public agencies have long been relied upon to provide unbiased information to the seed industry and to

Horticultural Sciences Dept., Gulf Coast Research and Education Center, University of Florida, Bradenton, FL 34203.

This research as supported by the Florida Agricultural Experiment Station and approved for publication as journal series no. R-08422. 
vegetable growers. There is less participation in vegetable variety evaluation by University of Florida faculty than in the past and this is likely true in many other states as well. Contributing factors are changes in assignment for existing faculty, revised position descriptions for new faculty, and perhaps less administrative recognition of cultivar evaluation than in the past. In the future, county extension faculty and professional staff will assume greater responsibility for traditional cultivar evaluation as the role of university faculty diminishes.

As these changes occur, university faculty efforts may be directed to evaluation of new crops, improvement of minor crops that have been neglected in the past, or other variations of traditional cultivar evaluation.

\section{Specialty vegetables}

Theimportance of specialtyvegetable crops has increased substantially in recent years. Specialty vegetables are a diverse group that include thosevegetables grown on small acreages (formerly called minor crops), ethnic vegetables, gourmet vegetables, miniature vegetables, greenhouse vegetables, and vegetables not usually grown in Florida. Production of specialty vegetables offers the opportunity of diversification for large growers and production of high-value crops by small growers that permit them to be competitive in the market place.

The dramatic increased popularity of specialty vegetables in the United States is related to a) increased awareness of ethnic vegetables among the population at large, and increased demand by the growing Hispanic-American and Asian-American communities; b) increased demand for new, unusual, or exotic vegetables by young, urban professionals; c) increased demand for gourmet vegetables by the food-service industry; and d) an increased awareness of the health and nutritional benefits of vegetables that contribute diversity to the diet, are high in nutrients and fiber, and low in calories, saturated fats, cholesterol, and sodium. Since these developments are driven by fundamental cultural, economic, and demographic forces, it can be anticipated that they will continue for some time to come.

Specialty vegetables (Table 1 ) have been evaluated in west-central Florida as one phase of the cultivar evaluation program. Some of these crops offer considerable production potential but

Table 1. Production potential of some specialty vegetables in west central Florida.

\begin{tabular}{|c|c|c|c|c|c|}
\hline \multirow[b]{2}{*}{ Vegetable } & \multirow[b]{2}{*}{ Botanical name } & \multicolumn{4}{|c|}{ Potential } \\
\hline & & None & Slight & Some & High \\
\hline Asparagus & Asparagus officinalis & & * & & \\
\hline Chinese radish & Raphanus satious & & & * & \\
\hline Garlic & Allium sativum & * & & & \\
\hline Globe artichoke & Cynara scolymus & & * & & \\
\hline Leek & Allium ampeloprasum & & & * & \\
\hline Miniature vegetables & Many & & & & * \\
\hline Okra & Abelmoschus esculentus & & & & * \\
\hline Pepper, Scotch Bonnet & Capsicum chinense & & & & * \\
\hline Pepino & Solanum muricatum & * & & & \\
\hline Pumpkin, decorative & Cucurbita pepo & & & * & \\
\hline Pumpkin, tropical & Cucurbita moschata & & & & * \\
\hline Radicchio & Cichorium endiva & & & * & \\
\hline Rhubarb & Rheum rhabarbarum & & & * & \\
\hline Shallot, sets & Allium сера & * & & & \\
\hline Shallot, seeds & Allium cepa & & * & & \\
\hline Snowpea & Pisum sativum & & & * & \\
\hline Spinach & Spinacia oleracea & & & & * \\
\hline Tomatillo & Physalis ixocarpa & & & & * \\
\hline Watermelon, icebox & Citrullis lanatus & & & & * \\
\hline Witloof chicory & Cichorium intybus & * & & & \\
\hline
\end{tabular}

marketing challenges have limited their adoption. Various specialty crops, including ornamentals and herbs, have been included in trials in north-central Florida. A marketing specialist is included in this educational program to provide a production-marketing linkage.

\section{Tropical pumpkin improvement}

The need for tropical pumpkin (Cucurbita moschata) crop improvement was noted during specialty crop cultivar and cultural evaluations. Traditional open-pollinated types developvery long vines and produce fruit over an extended period of time. Commercially produced seeds are not readily available so farmers generally rely on self-saved seeds. We reasoned that commercial production could be enhanced if a compact plant type with concentrated maturity was available. Furthermore, the improved type should be hybrid to encourage commercial seed availability because of the potential for profit.

Accordingly, the initial crosses were made in 1987 to obtain the compact plant habit from 'Bush Butternut' and Cornell 89-441-3 and the tropical pumpkin type from 'La Segunda', 'La Primera', and 'Seminole'. Selections were made for compact plant habit and tropical pumpkin fruit type at each generation. 'El Dorado' and 'La Estrella' tropical pumpkin hybrids with compact plant habit, concentrated maturity and high quality fruit have been developed from this program and are being proposed for introduction (Maynard et al., 2002).

\section{Conclusions}

University of Florida faculty, particularly those located at Research and Education Centers that are located strategically around the state, have been largely responsible for vegetable cultivar evaluations. For various reasons, the focus of vegetable crops research has shifted away from traditional cultivar evaluations in recent years. In the future, it is likely that cultivar evaluation in Florida will be conducted primarily by county extension faculty and professional staff. University faculty effort may be directed towards new crop evaluations and improvement of specialty crops.

\section{Literature cited}

Maynard, D.N. 1987. Vegetable variety evaluation demonstrations: A manual for county extension faculty. Fla. Coop. Ext. Serv. Circ. 762.

Maynard, D.N., G.W. Elmstrom, S.T. Talcott, and R. Bruce Carle. 2002. 'El Dorado' and 'La Estrella': Compact plant tropical pumpkin hybrids. HortScience (in press).

Maynard, D.N. and S.M. Olson. 200la. Vegetable variety trial results in Florida for 2000. Fla. Agr. Expt. Sta. Circ. S-396.

Maynard, D.N. and S.M. Olson. 2001b. Vegetable production guide for Florida. Citrus Veg. Mag., Tampa, Fla. 